\title{
COMPARATIVE ANALYSES OF HEALTH ECONOMICS INDICATORS IN THE EUROPEAN UNION AND TURKEY
}

\author{
Ali Unsal, $\mathrm{PhD}$ candidate, Lecturer'; Ewa Stawicka, $\mathrm{PhD}^{2}$ \\ ${ }^{1}$ Management and Organization Department, Bilecik Şeyh Edebali University \\ ${ }^{2}$ Faculty of Economic Sciences, Warsaw University of Life Sciences - SGGW
}

\begin{abstract}
In this paper, Turkey and the European Union countries are compared on health economics indicators such as health expenditure per capita, health expenditure as a percentage of GDP, life expectancy and infant mortality rate. The aim of this study is to determine the position of Turkey comparing to the European Union countries on the basis of health indicators. Result of this study shows that Eastern EU countries as well as, Turkey in particular should allocate more share for health from their health spendings to get better health outcomes.
\end{abstract}

Keywords: core health indicators, European Union countries, health expenditures

JEL codes: O1, I15

\section{INTRODUCTION}

Health spending is quantifying of the final consumption of health services and goods including personal healthcare such as curative health care and communal services such as prevention and public health services (OECD, 2013).

Physical, psychological and social health condition of a population have direct effect on its economic development (Grosse and Harkavy, 1980; Musgrove, 1993). Supposing that, if a person's health worsen, it would be impossible for herlhim to maintain even her his daily routine. The same, goes for a population; it is impossible for a population which comprise of unhealthy individuals to be productive and product any value-added production. When an individual or country spend on health, two kind of economic output will be obtained from this spending. First, waste of economic resources will be avoided since illnesses will be averted thanks to preventive health services and second, productivity of individuals will be increase. Therefore, health spending cannot be regarded as consumption spending, it should be regarded as capital expenditure.

In this study, health expenditure indicators and some other core health indicators such as life expectancy at birth, infant mortality are discussed in order to compare the European Union Member States and Turkey as a European Union candidate as well as to detect strengths and weaknesses of Turkey's health system.

\section{HEALTH SPENDINGS}

There is a strong relationship among income level of a country and its health expenditures, since income

${ }^{1}$ Corresponding author: Osmaneli, 11500 Bilecik, Turkey, ali.unsal@bilecik.edu.tr, +90545 7717101

${ }^{2}$ Corresponding author: Nowoursynowska 166,02-787 Warsaw, Poland, ewa_stawicka@sggw.pl, +4822 5934182 
Proceedings of the 2018 International Scientific Conference 'Economic Sciences for Agribusiness and Rural Economy' No 2, Warsaw, 7-8 June 2018, pp. 198-202

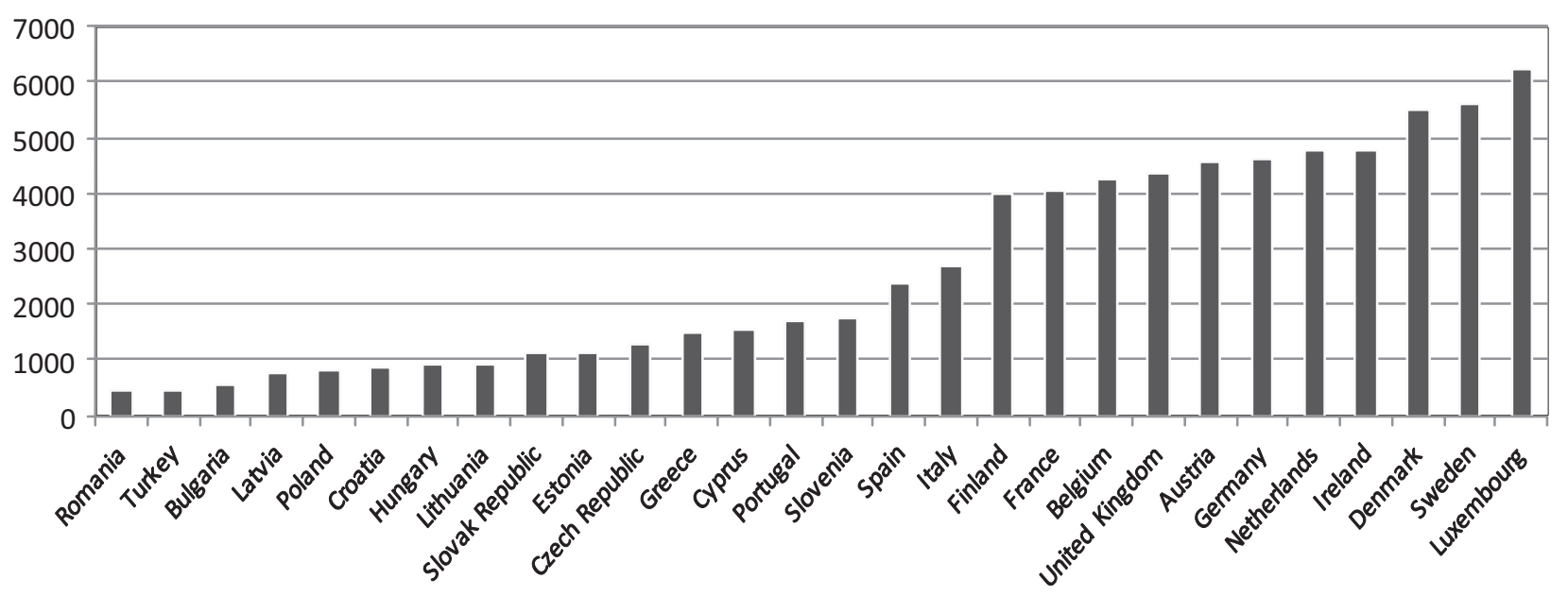

Figure 1. Health expenditure per capita in 2015 (USD)

Source: World Bank Databank (2015).

elasticity of health is high (Di Matteo, 2003; Farag et al., 2012). Preventive health care services and cosmetic health care services are accepted as luxury goods while primary, emergency and treatment health services are accepted as necessary goods (Hansen and King, 1996). That is why it is not surprising that countries such as Luxemburg, Sweden and Denmark took places near the top with such spending per capita more than USD 5,000. Turkey took place at second last after Romania with spending USD 453 per capita. Figure 1 shows health expenditure of the EU countries and Turkey in the year 2015.
In order to understand health expenditure level of countries we need to also consider health expenditures as a percentage of gross domestic product (GDP). Because sometimes, health expenditure as a share of GDP can be high while health expenditure per capita is low and vice versa. For instance, Luxemburg's health expenditure per capita is quite high (USD 6,236), while its health expenditure as a share of GDP is only around $6 \%$. This can be cause of the very high level of GDP of Luxemburg and the number of its inhabitants. Figure 2 shows health expenditure as a percentage of GDP of the EU countries and Turkey in the year of 2015.

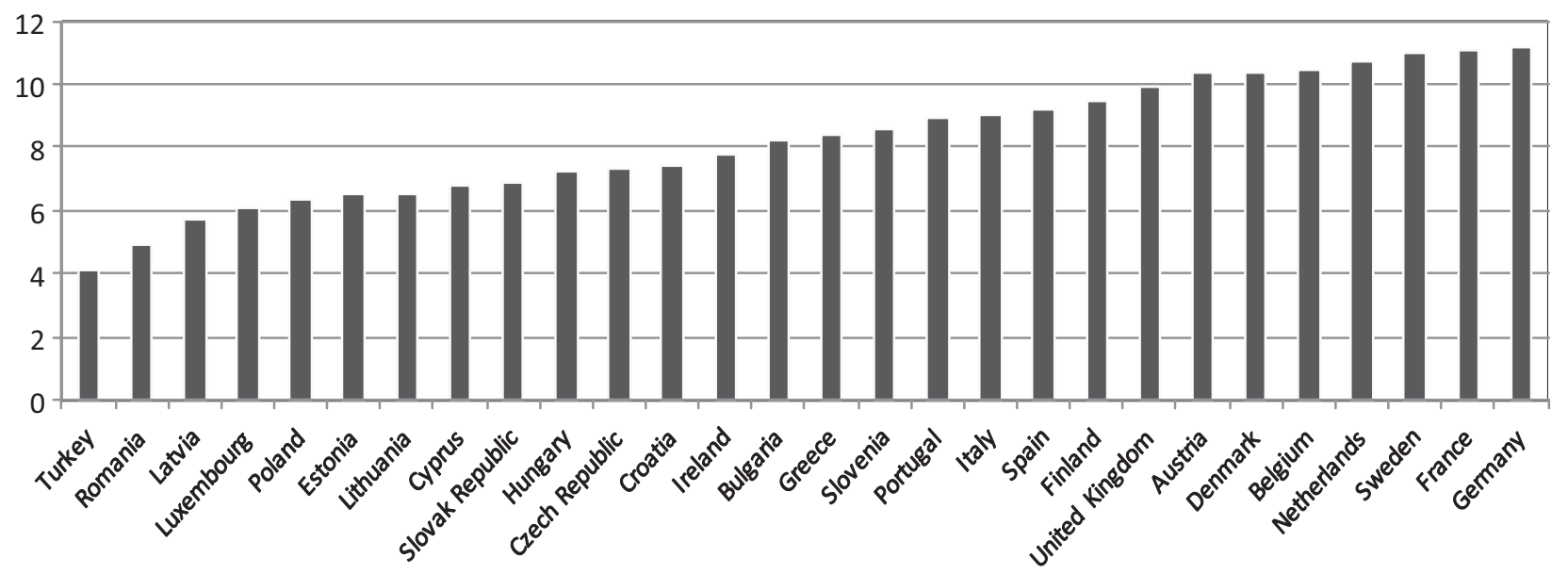

Figure 2. Health expenditure as a percentage of GDP in 2015 (USD per capita)

Source: World Bank Databank (2015). 
Germany, France and Sweden are the countries which allocate the biggest share from their GDP for health spending with more than $11 \%$ among EU countries. Turkey is the country which allocates the lowest share from its GDP for health spending with around 4\%. Other Eastern EU countries such as Romania, Latvia, Poland, Estonia, Lithuania, Cyprus, Bulgaria, Croatia, the Slovak Republic and the Czech Republic have lower both per capita expenditure (USD 2,789) and share of GDP (8.28\%) than average of the EU countries.

\section{CORE HEALTH INDICATORS}

There is no accurate indicator which measures the performance of health systems since it is difficult to determine the output of health systems. In the literature, health condition of a population is tried to be measured by specific measurements called core health indicators (Murray, Govindaraj and Musgrove, 1994). This core health indicators are used for making comparison between countries (Çevik, 2013). These indicators not only demonstrate health condition of a country but also demonstrate level of its development.

\section{Life expectancy at birth}

Life expectancy at birth is an indicator which measured for each country and each genders and it can be defined as how long, a new-born can expect to live, on average, if current death rates do not change. Figure 3 shows life expectancy at birth in EU countries and in Turkey.

As it seen at Figure 3, Mediterranean countries such as Spain and Italy have longest life expectancy years and Northern EU countries such as Sweden and Netherlands follow them respectively. Turkey and other Eastern EU countries such as Latvia, Lithuania, Bulgaria, Romania, Hungary, Croatia, Poland, the Slovak Republic, Estonia and the Czech Republic have lower life expectancy years than average of the European Union (79.4).

\section{Infant mortality rate}

The Infant mortality rate is the number of deaths in the first year of life occurring among the live births in a population during one year and it is measured per 1,000 births (OECD, 2017). This rate is the most important indicator that shows development level of a country. Figure 4 shows infant mortality rates of the EU countries and Turkey.

Figure 4 demonstrates an unacceptable rate for Turkey in the context of the European Union standards. In Turkey, almost 12 per thousand infant die before their first year of life. Most of Eastern EU countries such as Romania, Bulgaria, the Slovak Republic, Hungary, Latvia, Poland, Lithuania and Croatia have bigger mortality rates than European Union average (3.74).

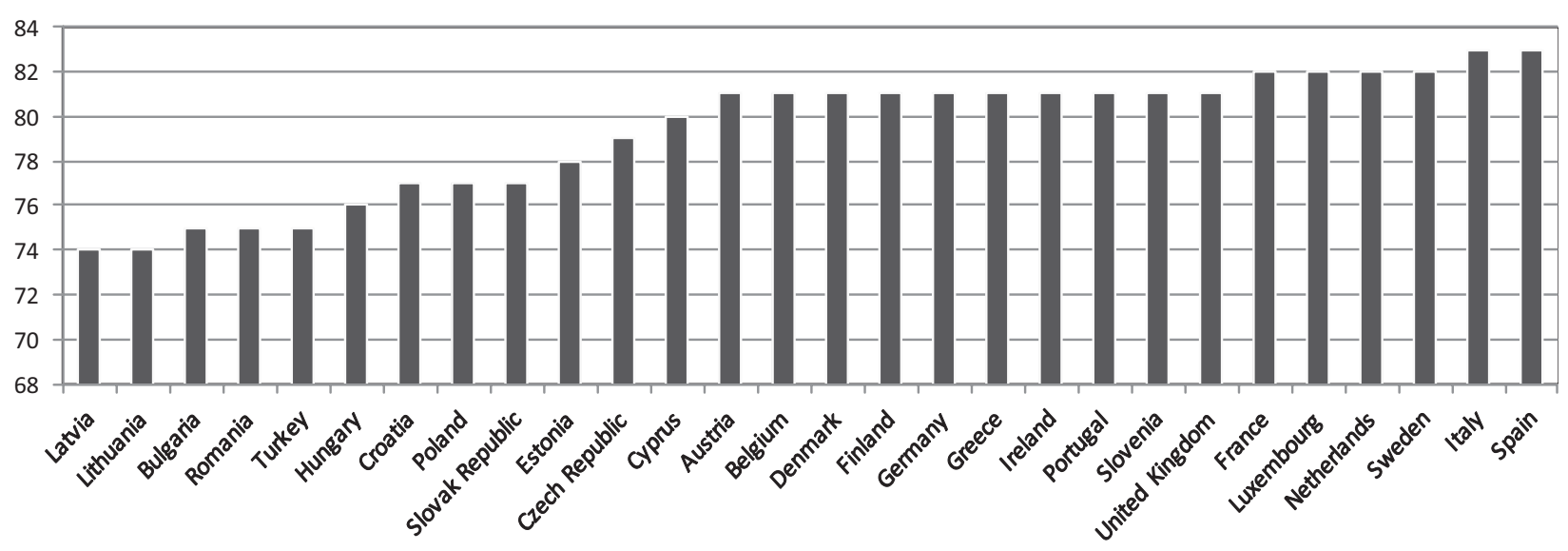

Figure 3. Life expectancy at birth in 2015 (years)

Source: World Bank Databank (2015). 


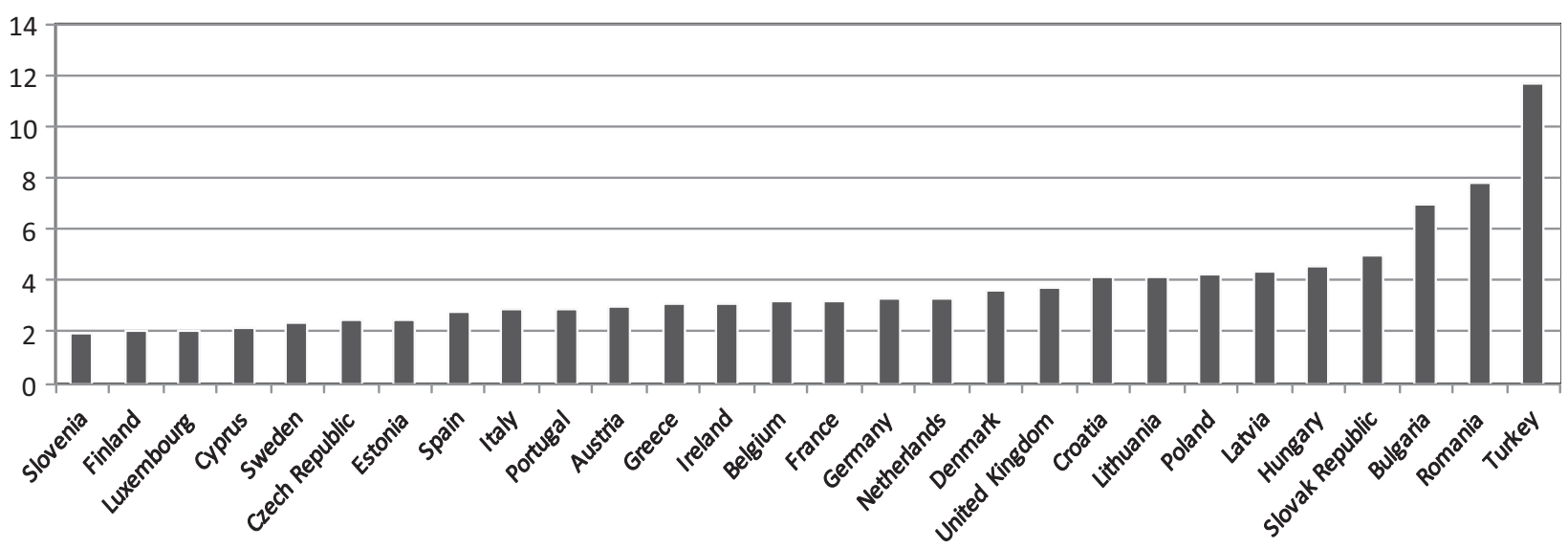

Figure 4. Infant mortality rate in 2015 (per 1,000 births)

Source: World Bank Databank (2015).

\section{CONCLUSIONS}

As a result, it is clearly seen that Turkey is the country that spends least for health among all EU countries. In return for such health spendings, it is not surprise that Turkey took the last place in infant mortality rates among all Europe and fall behind from the average of EU countries in life expectancy at birth.

As it mentioned before, main goal of paper is to compare EU countries and Turkey in terms of health indicators as well as to detect strengths and weaknesses of Turkish health system. According to findings, it can be clearly said that there is no strengths for Turkey's health indicators in comparison with EU countries. Turkey is at the last place along with Romania with regard to health expenditure per capita and health expenditure as a percentage of GDP indicators among the EU countries. These two countries have very similar health expenditure rates, however, Turkey has far worse infant mortality ratio than Romania does. This circumstance demonstrates two facts. First, Turkey not only spends less for health but also it wastes resources which are allocated for health. This fact may indicate that Turkish health system does not work properly. Second fact is that; health of populations is effected by several non-economic factors most particularly by life style.

Results of this study supports the literature (Tuyluoglu and Tekin, 2009; Çevik, 2013; Öngel, Altindağ and Öngel, 2014; Yalçın and Çakmak, 2016; Sayılı et al., 2017) which demonstrates strong correlation between health spendings and health outputs such as infant mortality and life expectancy. Therefore, Eastern EU countries, notably Turkey, should re-determine their priorities and increase the share of health spending from their GDP.

\section{REFERENCES}

1. Çevik, S. (2013).The Effect of Public Spending on the Improvement of Healthcare Services; A Comparative Study. İ.Ü. Siyasal Bilgiler Fakültesi Dergisi, 48 (48), pp. 113-134.

2. Di Matteo, L. (2003). The Income Elasticity of Health Care Spending: A Comparison Of Parametric and Nonparametric Approaches. European Journal of Health Economics. https://doi.org/10.1007/s10198-002-0141-6

3. Farag, M., NandaKumar, A.K., Wallack, S., Hodgkin, D., Gaumer, G., Erbil, C. (2012). The Income Elasticity of Health Care Spending in Developing and Developed Countries. International Journal of Health Care Finance and Economics, 12 (2), pp. 145-162. https://doi. org/10.1007/s10754-012-9108-z

4. Grosse, R., Harkavy, O. (1980). The Role of Health in development. Social Science \& Medicine Part C: Medical Economics, 14 (2), pp. 165-169.

5. Hansen, P., King, A. (1996). The Determinants of Health Care Expenditure: A Cointegration Approach. Journal of Health Economics. https://doi.org/10.1016/01676296(95)00017-8 
6. Murray, C.J., Govindaraj, R., Musgrove, P. (1994). National Health Expenditures: A Global Analysis. Bulletin of the World Health Organization, 72 (4), pp. 623-637.

7. Musgrove, P. (1993). Relations Between Health and Development. Boletín de la Oficina Sanitaria Panamericana, 114 (2), pp. 115-29.

8. OECD (2013). Health at a glance 2013: OECD Indicators. OECD Publishing, Paris. https://doi.org/10.1787/ health_glance-2013-en

9. OECD (2017). Health at a glance 2017: OECD Indicators. OECD Publishing, Paris. https://doi.org/10.1787/ health_glance-2017-en

10. Öngel, V., Altindağ, E., Öngel, G. (2014). The effect of Health Expenditure per Capita over Health Indicators: Comparative Analysis of MINT and BRIC Countries. International Conference on Eurasian Economies.
11. Sayıl1, U., Sayman, Ö., Vehid, S., Köksal, S., Erginöz, E. (2017). Comparison of Health Indicators and Health Expenditures of Turkey and OECD Countries. Online Türk Sağlık Bilimleri Dergisi, 2 (3), pp. 1-12.

12. Tuyluoglu, Ş., Tekin, M. (2009). The Effects of Income and Health Expenditures on Life Expectancy at Birth and Infant Mortality. Çukurova Üniversitesi IIBF Dergisi, 13 (1), pp. 1-31.

13. World Bank Databank (2015). World development indicators. Retrieved from: http://databank.worldbank. org/data/reports.aspx? source=world-development-indicators [Accessed 28.05.2018].

14. Yalçın, A., Çakmak, F. (2016). The Impact of Public Health Expenditures on Human Development in Turkey. Atatürk Üniversitesi IIBF Dergisi, 30 (4), pp. 705 -723 . 